ACTA UNIVERSITATIS NICOLAI COPER NICI

DOI: http://dx.doi.org/10.12775/AUNC_ECON.2016.001 EKONOMIA XLVII nr 1 (2016) 7-26

Pierwsza wersja złożona 15 czerwca 2016

e-ISSN: 2392-1269

Końcowa wersja zaakceptowana 19 września 2016

p-ISSN: 2080-0339

Michat Kupc, Krzysztof Makowski ${ }^{*}$

\title{
WYPŁATY DYWIDEND W SPÓŁKACH Z UDZIAŁEM ZAGRANICZNYCH INWESTORÓW BEZPOŚREDNICH ${ }^{* *}$
}

Z a r y s t r e ś c i. Dochody inwestorów bezpośrednich (głównie dywidendy) od lat stanowią istotną część ujemnego salda obrotów bieżących bilansu płatniczego. Autorzy podjęli się zadania weryfikacji wymienianych w literaturze przedmiotu czynników, wpływających na decyzje o wypłacie dywidend w przedsiębiorstwach $\mathrm{z}$ udziałem zagranicznego inwestora bezpośredniego, pod względem ich istotności i kierunku oddziaływania. W badaniu obejmującym lata 2012-2014, oszacowano tobitowe modele dla danych panelowych, uwzględniające m.in. finansowanie długiem. Analizę oparto na zbilansowanym panelu obejmującym 3437 jednostek.

S ło w a k l u c z o w e: dywidendy, zagraniczne inwestycje bezpośrednie, determinanty polityki dywidend przedsiębiorstw, tobitowy model dla danych panelowych.

K 1 a s y fik a c j a J E L: D22, F23, G30, G32, G35.

\section{WSTĘP}

Dochody inwestorów bezpośrednich stanowią od lat istotną część (zwykle ujemnego) salda rachunku bieżącego bilansu płatniczego Polski. Dzielą się one na trzy części: dywidendy wypłacane inwestorom, reinwestowane

\footnotetext{
* Adres do korespondencji: Michał Kupc, Departament Statystyki, Narodowy Bank Polski, ul. Świętokrzyska 11/21, 00-919 Warszawa, e-mail: michal.kupc@nbp.pl; Krzysztof Makowski, Departament Statystyki, Narodowy Bank Polski, ul. Świętokrzyska 11/21, 00-919 Warszawa, e-mail: krzysztof.makowski@nbp.pl.

${ }^{* *}$ Niniejszy artykuł odzwierciedla wyłącznie osobiste poglądy Autorów i nie przedstawia oficjalnego stanowiska NBP.

(C) 2016 Uniwersytet Mikołaja Kopernika. All rights reserved. http://www.aunc.ekonomia.umk.pl
} 
zyski pozostawiane w spółkach ${ }^{1}$ oraz odsetki. Podział zysków przedsiębiorstw na część reinwestowaną i wypłacaną $\mathrm{w}$ formie dywidendy jest niezwykle istotny z punktu widzenia kształtowania się potrzeb finansowych polskiej gospodarki.

Przedmiotem przeprowadzonej $\mathrm{w}$ niniejszym artykule analizy są dane podmiotów objętych sprawozdawczością na potrzeby bilansu płatniczego i międzynarodowej pozycji inwestycyjnej, które posiadają zagranicznych inwestorów bezpośrednich (podmioty bezpośredniego inwestowania) ${ }^{2}$. Na podstawie sprawozdań przesyłanych przez te podmioty, Narodowy Bank Polski przygotowuje zagregowane dane o zagranicznych inwestycjach bezpośrednich w Polsce. Zaprezentowane wyniki nie stanowią indywidualnych danych objętych obowiązującą NBP tajemnicą statystyczną.

W przygotowanym artykule, Autorzy podjęli się zadania weryfikacji, wymienianych w literaturze przedmiotu, czynników wpływających na decyzje o wypłacie dywidend. Czynniki te podlegały ocenie ze względu na ich istotność oraz kierunek oddziaływania. Były one weryfikowane wyłącznie w oparciu o dane podmiotów z udziałem zagranicznych inwestorów bezpośrednich, zatem wpływ samej obecności zagranicznego inwestora bezpośredniego na wypłaty dywidend nie podlegał statystycznej weryfikacji.

Kontrolując najczęściej spotykane w literaturze przedmiotu czynniki oddziałujące na wypłaty dywidend, Autorzy zweryfikowali również istotność efektów branżowych ${ }^{3}$ związanych $\mathrm{z}$ działalnością przedsiębiorstw z udziałem zagranicznego inwestora bezpośredniego.

Celem przeprowadzonej w artykule analizy polityki dywidendowej polskich przedsiębiorstw z udziałem zagranicznych inwestorów bezpośrednich jest nie tylko lepsze zrozumienie zachowania tych podmiotów (aspekt mikroekonomiczny), ale przede wszystkim dokładniejsze poznanie kształtowania się w czasie strumieni dochodów i napływu kapitału do polskiej gospodarki (aspekt makroekonomiczny).

\footnotetext{
${ }^{1}$ Wspomniane reinwestowane zyski odnotowywane są również w rachunku finansowym, aczkolwiek w rozumieniu napływu kapitału.

${ }^{2}$ Obowiązki i zasady tej sprawozdawczości wynikają z Rozporządzenia Ministra Finansów z dnia 23 października 2009 r. w sprawie przekazywania Narodowemu Bankowi Polskiemu danych niezbędnych do sporządzania bilansu płatniczego oraz międzynarodowej pozycji inwestycyjnej oraz Uchwały nr 78/2009 Zarządu Narodowego Banku Polskiego z dnia 29 października 2009 r. w sprawie trybu i szczegółowych zasad przekazywania przez banki Narodowemu Bankowi Polskiemu danych niezbędnych do sporządzania bilansu płatniczego oraz międzynarodowej pozycji inwestycyjnej.

${ }^{3}$ Poszczególne branże na potrzeby oszacowanego modelu, zostały określone na podstawie deklarowanej działalności firmy w sekcjach oraz podsekcjach Polskiej Klasyfikacji Działalności 2007 (NACE).
} 
Literatura prezentująca czynniki wpływające na podejmowane decyzje odnoszące się do wypłat dywidend jest obszerna, zarówno w odniesieniu do ogółu podmiotów wypłacających dywidendy, jak i w zakresie tych, notowanych na giełdach papierów wartościowych, bądź wyłącznie do przedsiębiorstw z udziałem zagranicznego inwestora bezpośredniego. Przeglądając zarówno opracowania teoretyczne, takie jak podręcznik finansów przedsiębiorstw Tirole'a (2006), czy też prace poświęcone w większym stopniu badaniom empirycznym (Kowerski, 2011; Jabłoński, 2014), wymienić można kilka najczęściej występujących czynników, wptywających pozytywnie na sama decyzję o wypłacie dywidendy, jak $i$ na jej wielkość (zarówno w wartościach bezwzględnych lub części strumienia zysków). Są to:

- fakt notowania akcji spółki na giełdzie papierów wartościowych,

- udział inwestorów „dywidendowych” w akcjonariacie spółki i stopień rozproszenia akcjonariatu,

- polityka stałej (stabilnej) dywidendy i częstotliwość jej wypłaty w poprzednich okresach,

- konkurencja i wynikający z niej stopień niepewności poziomu przyszłych wyników finansowych.

Z kolei czynnikami negatywnie oddziahującymi na wyptatę oraz wielkość dywidendy, są m.in. takie zmienne jak:

- wykup akcji lub udziałów, ze względu na preferencje podatkowe akcjonariuszy,

- brak obecności przedsiębiorstwa na rynkach giełdowych,

- stopień finansowania długiem.

Wspomniane czynniki oraz inne wskaźniki dotyczące m.in. płynności, rentowności, zadłużenia oraz form własności przedsiębiorstw, były w przeszłości często wykorzystywane do tworzenia modeli ekonometrycznych. Najczęściej stosowanym modelem w dotychczas prowadzonych badaniach (tzw. „modelem dywidendowym”) był model tobitowy (Wyrobek, 2004; AlMalkawi, 2007). W modelu tym, wartość dywidendy lub jej udział w zysku bądź kapitałach przyjmował wartości większe od zera, ze względu na fakt, iż nieobserwowalna zmienna skłonności do wypłaty dywidendy, przy obserwacjach (w postaci dywidendy) była cenzurowana $\mathrm{z}$ dołu, $\mathrm{tj}$. przy wartości „0” (zero). Równie często stosowaną, alternatywną specyfikacją, był model logitowy. Wypłatę dywidendy modelowano tu przy wykorzystaniu zmiennej przyjmującej wartość 0 (w przypadku braku wypłaty dywidendy) bądź 1 (w przeciwnym wypadku). Omówienie wspomnianych modeli wraz $\mathrm{z}$ uzasadnieniem ich stosowania, można odnaleźć m.in. w monografii Gruszczyńskiego (2012). 
Wiele publikowanych prac naukowych poświęconych jest empirycznej weryfikacji hipotez dotyczących skłonności do wypłat dywidend oraz innych wypłat dla akcjonariuszy. Zdecydowana większość z nich, ze względu na dostępność danych, ogranicza jednak analizę do podmiotów notowanych na Giełdzie Papierów Wartościowych w Warszawie (GPW). Tym samym, wykorzystany w niniejszym artykule nowy, szerszy zbiór danych, pozwolił na weryfikacje przytaczanych w literaturze przedmiotu czynników wpływających na wypłatę dywidend. O. Kowalewski (et al. 2007, 2012) zwrócił uwagę na pozytywny wpływ czynników związanych z corporate governance. A. Jurkowska (2008) analizowała zaś politykę dywidendową banków z punktu widzenia ich konserwatywnego (z definicji) zachowania oraz polityki reinwestowania zysków ${ }^{4}$. O wypłatach z kapitału jako alternatywy dla wypłaty dywidend pisała m.in. B. Horbaczewska (2012), która zwróciła uwagę na fakt, iż spółki notowane na GPW, w dużo mniejszym stopniu dzielą się zyskami niż spółki z rynków amerykańskich i Europy Zachodniej. $\mathrm{Z}$ innych badań, m.in. A. Zyguły (2015) wynika, że coraz mniej polskich spółek wypłaca dywidendy, których ogólna wartość pozostaje na w miarę stabilnym poziomie. Polski rynek kapitałowy cechuje pewna specyfika, obserwowana m.in. przez M. Wypycha (2015), który pokazał, iż spółki o rozproszonym akcjonariacie cechuje ograniczona skłonność do wypłaty dywidend.

Podejmowanie tematu wypłat dywidend przez podmioty z udziałem zagranicznych inwestorów bezpośrednich ma szczególne znaczenie w kraju takim jak Polska. Kraj nasz przez wiele lat był importerem kapitału zagranicznego, inwestowanego przez nierezydentów w oczekiwaniu na dochód, zarówno ten otrzymywany regularnie $\mathrm{w}$ formie dywidend, jak i ten wynikający ze wzrostu posiadanego majątku związanego ze wzrostem wartości inwestycji. W latach 2004-2015 dywidendy stanowiły około 30\% dochodów pierwotnych nierezydentów, zaś reinwestowane zyski (czyli ta część zysków, która nie została wypłacona w postaci dywidendy), w tym samym okresie, wynosiły prawie $70 \%$ napływu kapitału netto z tytułu inwestycji bezpośrednich.

W niniejszym artykule, Autorzy podjęli się zadania weryfikacji hipotezy mówiącej o tym, iż na wypłaty dywidend przez polskie podmioty z udziałem zagranicznych inwestorów bezpośrednich, wpływają te same czynniki jak w przypadku pozostałych podmiotów. Dodatkowo, w przeprowadzonym ba-

\footnotetext{
${ }^{4}$ Zjawisko to okazało się szczególnie istotne w czasie kryzysu finansowego na przełomie 2008 i 2009 roku, kiedy odnotowano duże (w porównaniu do zysków) wypłaty dywidend w celu ustabilizowania ich strumienia, o czym pisał m.in. Lewandowski (2010).
} 
daniu zweryfikowano wpływ działalności podmiotów w określonych branżach na skłonność do wypłat dywidend.

Postawiona $\mathrm{w}$ pracy hipoteza badawcza, została zweryfikowana przy pomocy ekonometrycznego modelu regresji opartego na danych panelowych z lat 2012-2014, uzyskanych od podmiotów z udziałem zagranicznych inwestorów bezpośrednich (sprawozdających się do NBP). Do wspomnianego modelu przyjęto zestaw zmiennych objaśniających odzwierciedlających czynniki wpływające na wypłatę dywidend we wszystkich podmiotach, w celu sprawdzenia czy są one istotne oraz jaki mają kierunek oddziaływania w przypadku badanych przedsiębiorstw. Ze względu na specyfikę wykorzystanych danych, odnoszących się wyłącznie do podmiotów z udziałem zagranicznego inwestora bezpośredniego, pominięto tym samym oszacowanie wpływu tej właściwości na skłonności do wypłat dywidend. Szczegółowy opis zastosowanych metod badawczych, zaprezentowano w dalszej części artykułu.

Struktura niniejszego artykułu jest następująca: w pierwszej części przedstawiono metodologię badania, w drugiej - charakterystykę zbioru danych. Trzecia część poświęcona jest modelowaniu decyzji o wypłacie dywidend (wykorzystano tu posiadane dane panelowe), zaś czwarta - prezentuje uzyskane wyniki. Analizę kończy podsumowanie oraz wskazanie możliwych dalszych kierunków badań.

\section{METODOLOGIA BADANIA}

Model tobitowy, nazwany tak przez A. S. Goldbergera (1964), został wprowadzony do literatury przedmiotu przez J. Tobina (1958). Model ten wykorzystywany do opisu zmiennej zależnej cenzurowanej, traktowany jest również jako ciągłe uogólnienie modelu probitowego poprzez uwzględnienie analizy regresji w opisie obserwowalnej części zmiennej zależnej. Przegląd podstawowych modeli tobitowych dla danych panelowych (ang. Tobit models for panel data) został zaprezentowany m.in. przez M. Gruszczyńskiego (1997).

Wykorzystane w niniejszym badaniu modele tobitowe, znajdują zwykle zastosowanie $\mathrm{w}$ analizach, w których wykorzystywane są zmienne objaśniane o następującym rozkładzie: znaczna część obserwacji zmiennej objaśnianej przyjmuje wartość odpowiadającą pewnej stałej (najczęściej wynoszącej zero), zaś pozostała część, kształtuje się na poziomie większym od tej stałej (tj. przyjmuje wartości dodatnie). Tym samym, na dotychczas zaprezentowanych histogramach opublikowanych $\mathrm{w}$ pracach badawczych poświęconych rozpatrywanej tematyce, można zaobserwować, iż znaczna częstość 
skoncentrowana jest w jednym punkcie, od którego na prawo występuje gruby „ogon” (asymetria prawostronna) (Gruszczyński, 2012). Przykładem zmiennej objaśnianej spełniającej wspomnianą charakterystykę jest uwzględniona $\mathrm{w}$ niniejszym badaniu zmienna tj. wartość dywidendy wypłaconej w danym roku. Dla większości z rozpatrywanych w analizie spółek wynosiła ona zero, zaś dla pozostałych obserwacji przyjmowała wartości większe od zera. Tym samym, w przypadku zastosowania przez Autorów klasycznego modelu regresji liniowej, konieczne byłoby pominięcie obserwacji zerowych, co powodowałoby konieczność oparcia wnioskowania statystycznego o zmiennej objaśnianej na pozostałych obserwacjach.

W celu zweryfikowania postawionych hipotez badawczych, Autorzy przyjęli następujące oznaczenia: $y$ - wysokość dywidendy wypłaconej przez spółki z udziałem zagranicznego inwestora bezpośredniego, $z$ - inne sposoby podziału zysku spółek z udziałem zagranicznego inwestora bezpośredniego, $x$ - całkowity zysk spółek $z$ udziałem zagranicznego inwestora bezpośredniego. Przy wspomnianych oznaczeniach, zadanie maksymalizacji funkcji użyteczności dane jest wzorem: $\max _{y, z} U(y, z)$, przy warunkach ograniczających przyjmujących postać: $y+z \leq x, y, z \geq 0$. Tak zdefiniowany problem decyzyjny zapisać można analitycznie $\mathrm{W}$ postaci: $y^{*}=\beta_{1}+\beta_{2} \times x+\varepsilon$, gdzie: $y^{*}-$ wartość dywidendy wypłaconej przez spółkę $\mathrm{w}$ przypadku braku ograniczeń (określana w literaturze przedmiotu jako zmienna utajona (ang. latent variable)), którą można zapisać jako: $y=y^{*}$ jeżeli $y^{*}>0$ bądź $y=0$ jeżeli $y^{*} \leq 0, x$ - czynniki wpływające na wysokość wypłaconej dywidendy przez spółki z udziałem zagranicznego inwestora bezpośredniego ${ }^{5}, \varepsilon$ - składnik losowy. W konsekwencji Autorzy otrzymali standardowy model tobitowy o postaci:

$$
y_{i}^{*}=x_{i}^{\prime} \beta+\varepsilon_{i},
$$

przy czym: $y_{i}=y_{i}^{*}$ jeżeli $y_{i}^{*}>0$ bądź $y_{i}=0$ jeżeli $y_{i}^{*} \leq 0$, gdzie: $i=1,2, \ldots, N, \varepsilon_{i} \sim N I D\left(0, \sigma^{2}\right)$ oraz jest niezależny od $x_{i}$.

$\mathrm{W}$ dostępnych publikacjach model (1) określany jest również mianem modelu cenzurowanej regresji (ang. Censored regression model, Verbeek, 2004), w którym to cenzura oznacza wyzerowanie mniejszych od zera war-

\footnotetext{
${ }^{5}$ Czynnikami tymi są m.in. struktura akcjonariatu, sytuacja finansowa przedsiębiorstwa, prowadzona w ostatnich latach polityka dywidendowa, sytuacja ekonomiczna branży.
}

AUNC, EKONOMIA XLVII nr 1 (2016) 7-26 
tości $y^{*}$ (tj. cenzurowanie $\mathrm{z}$ dołu). Z rozpatrywanego modelu wynika następująca zależność:

$$
\begin{gathered}
P\left\{y_{i}=0\right\}=P\left\{y_{i}^{*} \leq 0\right\}=P\left\{\varepsilon_{i} \leq-x_{i}^{\prime} \beta\right\}=P\left\{\frac{\varepsilon_{i}}{\sigma} \leq-\frac{x_{i}^{\prime} \beta}{\sigma}\right\}=\Phi\left(-\frac{x_{i}^{\prime} \beta}{\sigma}\right)=1-\Phi\left(\frac{x_{i}^{\prime} \beta}{\sigma}\right), \\
E\left\{y_{i} \mid y_{i}>0\right\}=x_{i}^{\prime} \beta+E\left\{\varepsilon_{i} \mid \varepsilon_{i}>-x_{i}^{\prime} \beta\right\}=x_{i}^{\prime} \beta+\sigma \frac{\phi\left(x_{i}^{\prime} \beta / \sigma\right)}{\Phi\left(x_{i}^{\prime} \beta / \sigma\right)} .
\end{gathered}
$$

gdzie: $\phi$ - funkcja gęstości, $\Phi$ - dystrybuanta zmiennej standaryzowanej o rozkładzie normalnym.

Estymacja modelu tobitowego (1) z reguły przeprowadzana jest z wykorzystaniem metody największej wiarygodności (MNW), zaś nieznane parametry szacowane są przy pomocy kwadratury Gaussa-Hermite'a (Wyrobek, 2004).

$\mathrm{W}$ przypadku przeprowadzenia badania przy wykorzystaniu danych panelowych, 13o bitowy model dla danych panelowych (ang. censored regression model for panel data bądź Panel Data Tobit Model), przyjmuje następującą postać:

$$
y_{i t}^{*}=x_{i t}^{\prime} \beta+\varepsilon_{i t}=x_{i t}^{\prime} \beta+\mu_{i}+v_{i t},
$$

przy czym: $y_{i t}=y_{i t}^{*}$ jeżeli $y_{i t}^{*}>0, \quad y=0 \quad$ jeżeli $y_{i t}^{*} \leq 0, \quad i=1,2 \ldots, N$, $t=1,2 \ldots, T, \quad v_{i t} \sim \operatorname{NID}\left(0, \sigma^{2}\right)$, gdzie: $\varepsilon_{i t}$ - łączny składnik losowy będący sumą losowych efektów indywidualnych oraz białego szumu, $v_{i t}-$ składnik losowy (biały szum), $\mu_{i}$ - składowa oznaczająca wpływ (niezależny od czasu) $i$-tej jednostki na $y$.

W literaturze, wśród rozpatrywanych tobitowych modeli dla danych panelowych, wyróżniane są: model z efektami statymi (ang. fixed effects model), model $z$ efektami losowymi (ang. random effects model) oraz autoregresyjny model tobitowy (ang, autoregressive model) (Gruszczyński, 1997; Henningsen, 2010). Przykładowy oszacowany w niniejszym artykule model tobitowy dla danych panelowych z efektami losowymi, dany jest wzorem:

$$
\begin{aligned}
& \text { DYW_ZYSKU } W_{i t}=\alpha+\beta_{1} \cdot \text { WYCOF_KAPIT } T_{i t}+\beta_{2} \cdot D Y W_{-} P O P_{i t}+ \\
& +\beta_{3} \cdot \text { WARIANCJA_ZYSKU } U_{i t}+\beta_{4} \cdot U D Z I A L_{-} S E K C J A_{i t}+\beta_{5} \cdot U D Z I A L_{i t}+ \\
& +\beta_{6} \cdot D L U G_{-} P A S Y W A_{i t}+\beta_{7} \cdot G P W_{i t}+\beta_{8} \cdot S P_{i t}+\beta_{9} \cdot S E K C J A a_{i t}+\varepsilon_{i t}, \\
& \text { przy czym } \varepsilon_{i t}=\mu_{i}+v_{i t}, \text { gdzie: } v_{i t} \sim \operatorname{NID}\left(0, \sigma^{2}\right) .
\end{aligned}
$$




\section{CHARAKTERYSTYKA DANYCH}

W przeprowadzonym badaniu wpływu czynników oddziałujących na podejmowane przez przedsiębiorstwa $\mathrm{z}$ udziałem zagranicznego inwestora bezpośredniego decyzje o wypłacie dywidend, wykorzystano panelowe dane zawierające następujące wskaźniki: finansowanie długiem w stosunku do całości pasywów (DLUG_PASYWA), udział danego przedsiębiorstwa z udziałem zagranicznego inwestora bezpośredniego w ramach danej sekcji PKD 2007 (UDZIAL_SEKCJA), udział danego przedsiębiorstwa z udziałem zagranicznego inwestora bezpośredniego w ramach podsekcji PKD 2007 (UDZIAL_PODSEKCJA), fakt działalności przedsiębiorstwa z udziałem zagranicznego inwestora bezpośredniego $\mathrm{w}$ danej sekcji (SEKCJA), udział głównego inwestora $\mathrm{w}$ przedsiębiorstwie $\mathrm{z}$ udziałem zagranicznego 14n14estorra bezpośredniego (UDZIAL), wariancja zysku ${ }^{6}$ (WARIANCJA_ZYS$\mathrm{KU})$, stosunek wypłaconej przez przedsiębiorstwo z udziałem zagranicznego inwestora bezpośredniego dywidendy do zysku danego przedsiębiorstwa (DYW_ZYSKU), stosunek wycofanego kapitału do kapitałów własnych na koniec okresu (WYCOF_KAPIT), stosunek długu do kapitałów własnych (DZWIGNIA), fakt notowania firmy na GPW (GPW), udział Skarbu Państwa (SP) oraz wypłacona dywidenda w poprzednich okresach (DYW_POP). Szczegółowe opis wspomnianych zmiennych przedstawiono w aneksie (por. tabela 1).

Wykorzystywane $\mathrm{w}$ artykule dane panelowe są danymi pochodzącymi bezpośrednio od podmiotów objętych sprawozdawczością z tytułu zaangażowania inwestorów bezpośrednich, będącymi podstawą do przygotowania, przez Narodowy Bank Polski, zagregowanych danych o zagranicznych 14 nwestycjach bezpośrednich ${ }^{7}$. Wspomniany panel na potrzeby przeprowadzonego badania został zbilansowany, tym samym uwzględnił on 3437 jednostek, tj. przedsiębiorstw z udziałem zagranicznego inwestora bezpośredniego.

${ }^{6} \mathrm{~W}$ niniejszym artykule pod pojęciem zysku rozumie się zysk z działalności bieżącej, zdefiniowany w międzynarodowych standardach dotyczących statystyki zagranicznych inwestycji bezpośrednich OECD (2008) jako Current Operating Performance Concept.

${ }^{7}$ Dane zbierane przez Narodowy Bank Polski na podstawie Rozporządzenia Ministra Finansów z dnia 23 października 2009 r. w sprawie przekazywania Narodowemu Bankowi Polskiemu danych niezbędnych do sporządzania bilansu płatniczego oraz międzynarodowej pozycji inwestycyjnej oraz Uchwały nr 78/2009 Zarządu Narodowego Banku Polskiego z dnia 29 października 2009 r. w sprawie trybu i szczegółowych zasad przekazywania przez banki Narodowemu Bankowi Polskiemu danych niezbędnych do sporządzania bilansu płatniczego oraz międzynarodowej pozycji inwestycyjnej. 
Podstawowe statystyki opisowe zmiennych wykorzystanych w badaniu, zaprezentowano w tabeli 1.

Tabela 1. Podstawowe statystyki opisowe wykorzystanych w badaniu zmiennych

\begin{tabular}{ccccc}
\hline & WARIANCJA_ZYSKU & UDZIAL & UDZIAL_SEKCJA & UDZIAL_PODSEKCJA \\
\hline Min & 0,000 & 0,000 & 0,000 & 0,000 \\
$Q_{1}$ & 0,100 & 99,000 & 0,000 & 0,000 \\
Mediana & 0,400 & 100,000 & 0,000 & 0,001 \\
Średnia & 682,900 & 91,390 & 0,004 & 0,013 \\
$Q_{3}$ & 2,600 & 100,000 & 0,001 & 0,005 \\
Maks & 2319831,800 & 100,000 & 1,000 & 1,000 \\
\hline & DZWIGNIA & DLUG_PASYWA & WYCOF_KAPIT & DYW_ZYSKU \\
\hline Min & $-29084,615$ & 0,000 & 0,000 & 0,000 \\
$Q_{1}$ & 0,000 & 0,008 & 0,000 & 0,000 \\
Mediana & 0,062 & 0,182 & 0,000 & 0,000 \\
Średnia & 0,630 & 1,145 & 0,021 & 0,188 \\
Q3 & 0,641 & 0,651 & 0,000 & 0,000 \\
Maks & 26899,458 & 1093,093 & 8,558 & 4,788 \\
\hline
\end{tabular}

Źródło: Opracowanie własne.

Na podstawie tabeli 1. Można stwierdzić, iż większość z rozpatrywanych w przeprowadzonej analizie zmiennych (za wyjątkiem zmiennej UDZIAL) charakteryzowało się asymetrią lewostronną, dla których to średnia przyjmowała wartości większe od mediany. Z kolei w odniesieniu do zmiennych zero-jedynkowych, tj. zmiennej SP oraz GPW, zaobserwowano zarówno stałą w czasie liczbę spółek posiadających w strukturze akcjonariatu udziały Skarbu Państwa jak i liczbę przedsiębiorstw notowanych na Giełdzie Papierów Wartościowych w Warszawie (tj. w przeciągu badanego okresu liczba spółek notowanych na GPW uległa nieznacznemu zwiększeniu, por. tabela 2.).

Tabela 2. Liczba spółek z udziałem zagranicznego inwestora bezpośredniego, z udziałem Skarbu Państwa oraz spółek notowanych na GPW w latach 2012-2014

\begin{tabular}{cccc}
\hline Okres & Liczba podmiotów & $\begin{array}{c}\text { Liczba podmiotów } \\
\text { z udziałem Skarbu Pań- } \\
\text { stwa }\end{array}$ & $\begin{array}{c}\text { Liczba podmiotów noto- } \\
\text { wanych na GPW }\end{array}$ \\
\hline 2012 & 3437 & 4 & 25 \\
2013 & 3437 & 4 & 28 \\
2014 & 3437 & 4 & 27 \\
\hline
\end{tabular}

Źródło: Opracowanie własne. 
A. Zyguła ( Zyguła 2015) w badaniu opartym na spółkach z GPW, odnotował spadek udziału spółek wypłacających dywidendy, który zmniejszył się z ponad 40\% w latach 2003-2008 do ok. 30\% w latach 2009-2011, przy czym wartość dywidend nie ulegała aż tak dużym zmianom. Wyniki analizy przeprowadzonej przez Autorów na zbiorze danych przedsiębiorstw z udziałem zagranicznego inwestora bezpośredniego (podobnej do powyższej), wskazały na niższy odsetek podmiotów wypłacających dywidendy, ale jednocześnie na nieznaczny spadek koncentracji dywidend w tych podmiotach. Szczegółowe wyniki zaprezentowano w tabeli 3.

Tabela 3. Odsetek i liczba dywidend wypłacanych przez podmioty objęte badaniem

\begin{tabular}{cccc}
\hline Okres & Liczba podmiotów & Liczba dywidend & $\begin{array}{c}\text { Odsetek podmiotów wy- } \\
\text { płacających dywidendy }\end{array}$ \\
\hline 2012 & 3437 & 748 & 0,218 \\
2013 & 3437 & 761 & 0,221 \\
2014 & 3437 & 820 & 0,239 \\
\hline
\end{tabular}

Źródło: Opracowanie własne.

Tabela 4. Udział największych dywidend w wartości dywidend ogółem w danym roku

\begin{tabular}{cccc}
\hline Liczba największych dywidend & 2012 & 2013 & 2014 \\
\hline 100 & 0,778 & 0,789 & 0,746 \\
200 & 0,889 & 0,891 & 0,862 \\
300 & 0,939 & 0,939 & 0,920 \\
400 & 0,967 & 0,967 & 0,954 \\
500 & 0,985 & 0,984 & 0,975 \\
\hline
\end{tabular}

Źródło: Opracowanie własne.

W analizowanym okresie skłonność do wypłat dywidend pozostawała na stałym poziomie, aczkolwiek była niższa niż w grupie podmiotów notowanych na Giełdzie Papierów Wartościowych w Warszawie. Koncentracja zaś, w przeciwieństwie do spółek giełdowych charakteryzowała się nieznaczną tendencją spadkową (por. tabela 4).

\section{KONSTRUKCJA EMPIRYCZNYCH MODELI WYPŁATY DYWIDEND}

$\mathrm{W}$ celu zweryfikowania postawionych w niniejszym artykule hipotez badawczych, Autorzy podjęli decyzję o oszacowaniu ekonometrycznych modeli dla danych panelowych w dwóch wariantach, uwzględniających takie zmienne jak: DYW_ZYSKU, WYCOF_KAPIT, DYW_POP, WARIANCJA_ZYSKU, UDZIAL, GPW, SP, SEKCJA, UDZIAL_PODSEKCJA, DZWIGNIA (wersja I) oraz DYW_ZYSKU, WYCOF_KAPIT, DYW_POP, 
WARIANCJA_ZYSKU, UDZIAL, GPW, SP, SEKCJA, UDZIAL_SEKCJA, DLUG_PASYWA (wersja II). Otrzymane wyniki zaprezentowano w aneksie (por. tabela II i tabela III).

Analizując tabelę II oraz tabelę III można stwierdzić, iż pomiędzy oszacowanymi modelami ekonometrycznymi dla danych panelowych ${ }^{8}$ (modele tobitowe) nie zaobserwowano znacznych różnic, zarówno w odniesieniu do kierunku oddziaływania, jak i co do istotności poszczególnych zmiennych ${ }^{9}$. Podobne wyniki (zarówno dla wariantu I jak i wariantu II) uzyskano również w odniesieniu do przeprowadzonej weryfikacji statystycznej. Zastosowane testy (test $\mathrm{F}$ badający istotność efektów stałych oraz test Hondy analizujący istotność efektów losowych), wskazały iż model within z efektami czasowymi oraz model between z efektami grupowymi jest lepszy niż model pooled. $\mathrm{Z}$ kolei w przypadku modelu random z efektami czasowymi, zakłada się brak efektów grupowych (podjęto decyzję weryfikacyjną o braku podstaw do odrzucenia hipotezy zerowej). Na podstawie testów Hausmana, BreuschaPagana oraz Breuscha-Godfrey'a stwierdzono natomiast, iż w przypadku wszystkich oszacowanych modeli estymator fixed effects posiada lepsze własności niż estymator random effects oraz, że w modelach występują zjawiska heteroskedastyczności i autokorelacji.

Ze względu na specyfikację tobitowego modelu dla danych panelowych $\mathrm{z}$ efektami losowymi, charakteryzującego się m.in. dużą liczbą stopni swobody $^{10}$, wykorzystywaniem w przypadku stosowania danych panelowych o dużej liczbie jednostek $N$ oraz odznaczającym się zwykle bardziej efektywnym estymatorem niż estymator modelu $\mathrm{z}$ efektami stałymi (Kopczewskai inni, 2009), Autorzy podjęli decyzję o wyborze wspomnianego modelu jako głównego narzędzia umożliwiającego weryfikację postawionych hipotez badawczych. Tym samym, pominięto wnioski uzyskane z testu Hausmana, który został przeprowadzony na zbilansowanym panelu danych dla lat 2012-2014, odnoszących się do przedsiębiorstw z udziałem zagranicznego inwestora bezpośredniego.

Celem dalszych badań czynników wypływających na decyzje o wypłacie dywidend $\mathrm{w}$ przedsiębiorstwach $\mathrm{z}$ udziałem zagranicznego inwestora bezpo-

\footnotetext{
${ }^{8}$ Rozpatrywane modele ekonometryczne zostały oszacowane w oparciu o zbilansowany panel.

${ }^{9}$ Dla większości z uwzględnionych w modelach zmiennych, przy poziomie istotności $\alpha=0,1$ podjęto decyzję weryfikacyjną o odrzuceniu hipotezy zerowej o nieistotności parametrów na korzyść hipotezy alternatywnej.

${ }^{10} \mathrm{~W}$ przeciwieństwie do modelu z efektami stałymi, w którym to liczba stopni swobody jest drastycznie obniżana na skutek konieczności dodawania wielu zmiennych zerojedynkowych.
} 
średniego, w zakresie ich istotności oraz kierunku oddziaływania, będzie wykorzystanie innych (w stosunku do zastosowanych w artykule) metod ekonometrycznych, np. modelu Feaslible Generalized Least Square (FGLS), bądź przeprowadzenie ważenia danych pierwiastkiem kwadratowym zmiennych podejrzewanych o generowanie heteroskedastyczności. Jednocześnie przy wyborze nowych metod, uwzględnione zostanie podejście polegające na pominięciu efektów czasowych, ze względu na małą liczbę okresów ( $T$ ).

\section{WYNIKI BADAŃ}

Badanie wpływu czynników oddziałujących na podejmowane przez przedsiębiorstwa $\mathrm{z}$ udziałem zagranicznego inwestora bezpośredniego decyzje o wypłacie dywidend, dla lat 2012-2014, przeprowadzono przy wykorzystaniu ekonometrycznych modeli dla danych panelowych ( $\mathrm{tj}$. modeli tobitowych), oszacowanych w oparciu o zbilansowany panel obejmujący 3437 jednostek. W analizie uwzględniono takie zmienne jak: finansowanie długiem $\mathrm{w}$ stosunku do całości pasywów, udział danego przedsiębiorstwa $\mathrm{z}$ udziałem zagranicznego inwestora bezpośredniego $\mathrm{w}$ ramach danej sekcji/podsekcji PKD 2007 (NACE), fakt działalności przedsiębiorstwa z udziałem zagranicznego inwestora bezpośredniego w danej sekcji, udział głównego inwestora w przedsiębiorstwie $\mathrm{z}$ udziałem zagranicznego inwestora bezpośredniego, wariancja zysku, stosunek wypłaconej przez przedsiębiorstwo z udziałem zagranicznego inwestora bezpośredniego dywidendy do zysku danego przedsiębiorstwa, stosunek wycofanego kapitału do kapitałów własnych na koniec okresu, stosunek długu do kapitałów własnych, a także trzy zmienne zero-jedynkowe, tj. wypłacona dywidenda w poprzednich okresach, notowanie przedsiębiorstwa na GPW oraz udział Skarbu Państwa.

W wyniku przeprowadzonego badania empirycznego stwierdzono, iż pośród szeregu analizowanych czynników wyróżnia się zarówno zmienne, których oddziaływanie na zmienną objaśnianą jest zgodne z ogólnymi teoriami finansów przedsiębiorstw, jak również zmienne, których kierunek wpływu lub istotność można wytłumaczyć specyfiką doboru próby. Ponadto, kontrolując parametry związane $\mathrm{z}$ charakterystykami finansowymi przedsiębiorstw, stwierdzono istotny wpływ na politykę dywidendową branż, w których działają firmy stanowiące populację sprawozdawczą.

Zgodny z teoriami głoszącymi stałość wypłat dywidend, silny i istotny statystycznie wpływ, zarówno na wypłatę dywidend, jak również ich udział w zysku, w latach 2012-2014 miała zmienna opisująca wypłatę dywidend w poprzednim okresie. Równie statystycznie istotnymi, ale o mniejszej sile oddziaływania, okazały się czynniki opisujące wypłaty z kapitału oraz udział 
największych akcjonariuszy. Wpływały one pozytywnie na skłonność do wypłat dywidend i ich wartość. W przypadku udziału największych akcjonariuszy, uzyskane z przeprowadzonego badania wyniki, stanowiły potwierdzenie wniosków z analizy M. Wypycha (2015), inaczej niż w przypadku wniosków opartych głównie na danych z giełd amerykańskich. Natomiast w odniesieniu do wypłat $\mathrm{z}$ kapitału, niespodziewany kierunek oddziaływania mógł być konsekwencją przyjętych w sprawozdawczości standardów statystycznych, klasyfikujących wypłatę dywidendy z kapitałów rezerwowych jako wycofanie kapitału, a nie jako dywidendę. W konsekwencji istnieje prawdopodobieństwo, iż $\mathrm{w}$ tych samych okresach kiedy przedsiębiorstwa wypłacały dywidendę z zysku bieżącego, mogły wypłacać również dywidendę z zysku $\mathrm{z}$ lat poprzednich.

Istotny (dodatni) wynik oszacowania odnotowano także w przypadku zmiennej opisującej udział danego przedsiębiorstwa w określonej sekcji/podsekcja $\mathrm{PKD}^{11}$. O ile w teorii ekonomii większa konkurencja, a więc mniejszy udział w branży, powinny zwiększać skłonność do wypłaty dywidendy (ze względu na potencjalnie mniejsze zyski w przyszłości), to z drugiej strony większy udział, a co za tym idzie większą siłę rynkową, można interpretować jako większy potencjał do generowania stałych zysków i regularnej ich dystrybucji.

W oszacowanych modelach tobitowych dla danych panelowych (wersja I i wersja II), zmiennymi statystycznie nieistotnymi, okazały się takie zmienne jak: obecność Skarbu Państwa w akcjonariacie przedsiębiorstwa, notowanie na GPW, udział długu w pasywach spółki, wariancja zysku oraz dźwignia finansowa.

Oprócz wspomnianych zmiennych objaśniających, w użytym do analizy estymowanym modelu ekonometrycznym uwzględniono także zmienne opisujące przynależność podmiotów do różnych sekcji rodzaju działalności gospodarczej wg PKD 2007 (NACE). Istotny i pozytywny wpływ określonych branż odnotowano w przypadku branż: przetwórstwa przemysłowego, handlu oraz pośrednictwa finansowego i doradztwa w zakresie zarządzania. O ile w przypadku tych dwóch pierwszych wymienionych sekcji, wiązało się to ze stosunkowo wysoką rentownością zainwestowanych kapitałów, to w przypadku pośrednictwa finansowego i doradztwa w zakresie zarządzania (ze względu na duży udział holdingów finansowych i firm centralnych), wynik jest trudniejszy do interpretacji.

\footnotetext{
${ }^{11}$ Wskaźnik ten jest pewnym przybliżeniem siły rynkowej danego przedsiębiorstwa.
} 


\section{PODSUMOWANIE}

Korzystając ze zmiennych dostępnych w zbiorze danych o podmiotach z udziałem zagranicznych inwestorów bezpośrednich, Autorom udało się potwierdzić wpływ wypłat dywidend w poprzednim okresie, innych wypłat z kapitału, udziału największych akcjonariuszy, udziału firmy w ramach danej sekcji/podsekcji PKD.

W zakresie czynników, które były przedmiotem analizy, Autorom udało się potwierdzić hipotezę, iż na wypłaty dywidend przez polskie podmioty z udziałem zagranicznych inwestorów bezpośrednich wpływają te same czynniki, co w przypadku innych podmiotów. Dodatkowo, Autorzy wykazali wpływ specyfiki branżowej na skłonność do wypłat dywidend.

Artykuł stanowi uzupełnienie dotychczasowego stanu wiedzy w obszarze skłonności do wypłaty dywidend podmiotów z udziałem zagranicznego inwestora bezpośredniego oraz inspiruje do dalszych analiz opartych na rozszerzonym zestawie czynników lub przy wykorzystaniu odmiennych metod badawczych.

\section{LITERATURA}

Al-Malkawi H.-A.N. (2007), Determinants of Corporate Dividend Policy in Jordan: An Application of Tobit Model, „Journal of Economic and Administrative Sciences”, 23(2), 44-70, DOI: http://dx.doi.org/10.1108/10264116200700007.

Berent T. (2013), Ogólna teoria dźwigni finansowej, Oficyna Wydawnicza SGH, Warszawa.

Goldberger A. S. (1964), Econometric Theory, Wiley, New York.

Gruszczyński M. (1997), Dynamiczne modele tobitowe, „Przegląd Statystyczny”, 4.

Gruszczyński M. (2012), Empiryczne finanse przedsiębiorstw. Mikroekonometria finansowa, Diffin, Warszawa.

Henningsen A. (2010), Estimating censored regression models in $R$ using the "censReg" package. Vignette to the $R$ package censReg, CRAN, https://cran.rproject.org/web/packages/censReg/vignettes/censReg.pdf (28.04.2016).

Horbaczewska B. (2012), Wypłaty dla akcjonariuszy a wycena akcji na rynku kapitałowym, Wydawnictwo CeDeWu, Warszawa.

Jabłoński B. (2014), Determinanty polityki dywidend, Zeszyty Naukowe Uniwersytetu Ekonomicznego w Katowicach nr 177, Studia Ekonomiczne, Inwestycje i nieruchomości wybrane zagadnienia, Katowice, 98-109.

Jurkowska A. (2008), Czy banki zagraniczne transferuja zyski?, Zeszyty Naukowe / Uniwersytet Ekonomiczny w Krakowie, 778, 85-98.

Kopczewska K., Kopczewski T., Wójcik P. (2009), Metody ilościowe w R. Aplikacje ekonomiczne i finansowe, Wydawnictwo CeDeWu, Warszawa.

Kowalewski O., Stetsyuk I., Talavera O. (2007), Corporate governance and dividend policy in Poland, Wharton Financial Institutions Center Working Paper, 07-09, 1-35, DOI: http://dx.doi.org/10.2139/ssrn.986111. 
Kowalewski O. (2012), Does Corporate Governance Determine Corporate Performance and Dividends During Financial Crisis: Evidence from Poland, Wharton Financial Institutions Center Working Paper, 12-14, 1-40,

DOI: http://dx.doi.org/10.2139/ssrn.2146168.

Kowerski M. (2011), Ekonomiczne uwarunkowania decyzji o wypłacie dywidend przez spółki publiczne, Wydawnictwo Konsorcjum Akademickie.

Lewandowski R. (2010), Dywidenda na polskim rynku giełdowym, Przegląd Organizacji, 6.

OECD (2008), OECD Benchmark Definition of Foreign Direct Investment - fourth edition, OECD.

Tirole J. (2006), The theory of corporate finance, Princeton University Press.

Tobin J. (1958), Estimation of relationship for limited dependent variables, „Econometrica”, 26(1), 24-36, DOI: http://dx.doi.org/10.2307/1907382.

Verbeek M. (2004), A guide to modern econometrics, Routledge, London.

Wypych M. (2015) Koncentracja własności a wyplata dywidend na przykładzie przemystowych spótek giełdowych, Zeszyty Naukowe Uniwersytetu Szczecińskiego, 854, „Finanse, Rynki Finansowe, Ubezpieczenia”, 73, Wydawnictwo Naukowe Uniwersytetu Szczecińskiego, Szczecin, 783-792.

Wyrobek J. (2004), Polityka dywidend w spótkach notowanych na Giełdzie Papierów Wartościowych $w$ Warszawie w latach 1994-2002, Zeszyty Naukowe PTE, 2, 237-261.

Zyguła A. (2015), Polityka dywidendowa spótek z większościowym udziałem kapitału zagranicznego - tendencje, Zeszyty Naukowe Uniwersytetu Szczecińskiego nr 855, „Finanse, Rynki Finansowe, Ubezpieczenia”, 74(1), Wydawnictwo Naukowe Uniwersytetu Szczecińskiego, Szczecin, 229-239, DOI: http://dx.doi.org/10.18276/frfu.2015.74/1-20.

\title{
DIVIDEND PAYMENTS IN COMPANIES WITH FOREIGN DIRECT INVESTORS
}

\begin{abstract}
A b s t r a c t. Direct investors income (mainly dividends) are an important part of the negative current account balance of the balance of payments. The authors verified the impact of the factors presented in the literature on the dividend payout decisions of companies with foreign direct investors in terms of their significance and the direction of impact. In the analysis authors estimated tobit models on panel data for the years 2012-2014. The analysis was based on a balanced panel comprising 3437 units.
\end{abstract}

Ke y w ords: dividend, foreign direct investment, determinants of the dividend policy of companies, Panel Data Tobit Models. 


\section{ANEKS}

Tabela I. Opis wykorzystanych w badaniu zmiennych

\begin{tabular}{|c|c|c|}
\hline $\begin{array}{c}\text { Nazwa zmiennej } \\
\text { w modelu }\end{array}$ & Pełna nazwa zmiennej & Opis \\
\hline WYCOF_KAPIT & Wycofanie kapitału & $\begin{array}{l}\text { Stosunek wycofanego kapitału do kapitałów } \\
\text { własnych na koniec okresu w przedsiębiorstwie } \\
\text { z udziałem zagranicznego inwestora } \\
\text { bezpośredniego. }\end{array}$ \\
\hline DYW_POP & $\begin{array}{c}\text { Dywidenda w poprzednich } \\
\text { okresach }\end{array}$ & $\begin{array}{l}\text { Zmienna zero-jedynkowa przyjmująca wartość } \\
1, \text { gdy spółka z udziałem zagranicznego } \\
\text { inwestora bezpośredniego wypłaciła w okresie } \\
\text { poprzednim dywidendę, bądź wartość } 0 \\
\text { w przeciwnym wypadku. }\end{array}$ \\
\hline WARINACJA_ZYSKU & $\begin{array}{c}\text { Wariancja zysku } \\
\text { w poprzednich latach }\end{array}$ & $\begin{array}{l}\text { Wariancja wystandaryzowanego zysku } \\
\text { w poprzednich latach w przedsiębiorstwie } \\
\text { z udziałem zagranicznego inwestora } \\
\text { bezpośredniego (tj. wariancja zysku z 2010r. do } \\
\text { wariancji zysku z okresu } t-1 \text { ).Wspomniana } \\
\text { standaryzacja przeprowadzona została poprzez } \\
\text { wyliczenie stosunku zysku bieżącego danego } \\
\text { przedsiębiorstwa z udziałem zagranicznego } \\
\text { inwestora bezpośredniego z danego roku do } \\
\text { średniego zysku bieżącego w danej spółce } \\
\text { z udziałem zagranicznego inwestora } \\
\text { bezpośredniego ze wszystkich lat. }\end{array}$ \\
\hline UDZIAL_SEKCJA & $\begin{array}{l}\text { Udział } \\
\text { danego przedsiębiorstwa z } \\
\text { udziałem zagranicznego } \\
\text { inwestora bezpośredniego } \\
\text { w ramach danej sekcji } \\
\text { Polskiej Klasyfikacji } \\
\text { Działalności } 2007\end{array}$ & $\begin{array}{l}\text { Stosunek pasywów zagranicznych } \\
\text { przedsiębiorstwa z udziałem zagranicznego } \\
\text { inwestora bezpośredniego w danej sekcji } \\
\text { w danym roku do sumy pasywów } \\
\text { zagranicznych wszystkich podmiotów } \\
\text { z udziałem zagranicznego inwestora } \\
\text { bezpośredniego w danej sekcji w danym roku. }\end{array}$ \\
\hline UDZIAL_PODSEKCJA & $\begin{array}{l}\text { Udział } \\
\text { danego przedsiębiorstwa z } \\
\text { udziałem zagranicznego } \\
\text { inwestora bezpośredniego } \\
\text { w ramach danej podsekcji } \\
\text { Polskiej Klasyfikacji } \\
\text { Działalności } 2007\end{array}$ & $\begin{array}{l}\text { Stosunek pasywów zagranicznych } \\
\text { przedsiębiorstwa z udziałem zagranicznego } \\
\text { inwestora bezpośredniego w danej podsekcji } \\
\text { w danym roku do sumy pasywów } \\
\text { zagranicznych wszystkich podmiotów } \\
\text { z udziałem zagranicznego inwestora } \\
\text { bezpośredniego w danej podsekcji w danym } \\
\text { roku. }\end{array}$ \\
\hline UDZIAL & Udział głównego inwestora & $\begin{array}{l}\text { Udział głównego inwestora w przedsiębiorstwie } \\
\text { z udziałem zagranicznego inwestora } \\
\text { bezpośredniego. }\end{array}$ \\
\hline
\end{tabular}

AUNC, EKONOMIA XLVII nr 1 (2016) 7-26 
Tabela I. ciąg dalszy

\begin{tabular}{|c|c|c|}
\hline $\begin{array}{c}\text { Nazwa zmiennej } \\
\text { w modelu }\end{array}$ & Pełna nazwa zmiennej & Opis \\
\hline DLUG_PASYWA & $\begin{array}{c}\text { Finansowania długiem } \\
\text { w stosunku do całości } \\
\text { pasywów }\end{array}$ & $\begin{array}{l}\text { Stosunek finansowania długiem danego } \\
\text { przedsiębiorstwa z udziałem zagranicznych } \\
\text { inwestorów bezpośrednich od zagranicznych } \\
\text { podmiotów powiązanych w danym roku do } \\
\text { całości pasywów zagranicznych danego } \\
\text { przedsiębiorstwa z udziałem zagranicznego } \\
\text { inwestora bezpośredniego w danym roku. }\end{array}$ \\
\hline DZWIGNIA & Dźwignia finansowa & $\begin{array}{l}\text { Stosunek finansowania długiem danego } \\
\text { przedsiębiorstwa z udziałem zagranicznych } \\
\text { inwestorów bezpośrednich od zagranicznych } \\
\text { podmiotów powiązanych w danym roku do } \\
\text { kapitałów własnych przypadających na } \\
\text { inwestora bezpośredniego w przedsiębiorstwie } \\
\text { z udziałem zagranicznego inwestora } \\
\text { bezpośredniego w danym roku. }\end{array}$ \\
\hline DYW_ZYSKU & Udział dywidendy w zysku & $\begin{array}{l}\text { Wartość dywidendy w przedsiębiorstwie } \\
\text { z udziałem zagranicznego inwestora } \\
\text { bezpośredniego w danym roku do zysku } \\
\text { przedsiębiorstwa z udziałem zagranicznego } \\
\text { inwestora bezpośredniego w okresie } \\
\text { poprzednim. }\end{array}$ \\
\hline GPW & $\begin{array}{c}\text { Notowanie } \\
\text { przedsiębiorstwa z } \\
\text { udziałem zagranicznego } \\
\text { inwestora bezpośredniego } \\
\text { na Giełdzie Papierów } \\
\text { Wartościowych w } \\
\text { Warszawie w danym roku }\end{array}$ & $\begin{array}{l}\text { Zmienna zero-jedynkowa przyjmująca wartość } \\
1, \text { gdy przedsiębiorstwo z udziałem } \\
\text { zagranicznego inwestora bezpośredniego jest } \\
\text { notowana na GPW w Warszawie w danym } \\
\text { roku, bądź wartość } 0 \text { w przeciwnym wypadku. }\end{array}$ \\
\hline SP & $\begin{array}{l}\text { Udział Skarbu Państwa } \\
\text { w przedsiębiorstwie } \\
\text { z udziałem zagranicznego } \\
\text { inwestora bezpośredniego }\end{array}$ & $\begin{array}{l}\text { Zmienna zero-jedynkowa przyjmujacca wartość } \\
1 \text {, gdy przedsiębiorstwo z udziałem } \\
\text { zagranicznego inwestora bezpośredniego } \\
\text { posiada udziały Skarbu Państwa, bądź wartość } \\
0 \text { w przeciwny wypadku. }\end{array}$ \\
\hline
\end{tabular}

AUNC, EKONOMIA XLVII nr 1 (2016) 7-26 
Tabela I. ciąg dalszy

\begin{tabular}{|c|c|c|}
\hline $\begin{array}{l}\text { Nazwa zmiennej } \\
\text { w modelu }\end{array}$ & Pełna nazwa zmiennej & Opis \\
\hline SEKCJA & $\begin{array}{c}\text { Sekcja Polskiej } \\
\text { Klasyfikacji Działalności } \\
2007\end{array}$ & $\begin{array}{l}\text { Klasyfikacja działalności gospodarczej danego } \\
\text { przedsiębiorstwa z udziałem zagranicznego } \\
\text { inwestora bezpośredniego według sekcji, } \\
\text { przyjmującej następujace oznaczenia: } \\
\text { A - rolnictwo, leśnictwo i rybactwo; } \\
\text { B - górnictwo i wydobywanie; C - przetwórstwo } \\
\text { przemysłowe; D - wytwarzanie i zaopatrywanie } \\
\text { w energię elektryczna, gaz, parę wodną } \\
\text { i powietrze do układów klimatyzacyjnych; } \\
\text { E - dostawa wody; gospodarowanie ściekami } \\
\text { i odpadami oraz działalność zwiazzana } \\
\text { z rekultywacja; F - budownictwo; G - handel } \\
\text { hurtowy i detaliczny; naprawa pojazdów } \\
\text { samochodowych i motocykli; H - transport } \\
\text { i gospodarka magazynowa; I - działalność } \\
\text { zwiazzana z zakwaterowaniem i usługami } \\
\text { gastronomicznym; J - informacja } \\
\text { i komunikacja; K - działalność finansowa } \\
\text { i ubezpieczeniowa; L - działalność zwiazana } \\
\text { z obsługa rynku nieruchomości; M - działalność } \\
\text { profesjonalna, naukowa i techniczna; } \\
\text { N - działalność w zakresie usług } \\
\text { administrowania i działalność wspierająca; } \\
\text { NAL - pozostałe sekcje PKD; O - administracja } \\
\text { publiczna i obrona narodowa, obowiazzkowe } \\
\text { zabezpieczenia społeczne; P - edukacja; } \\
\text { Q - opieka zdrowotna i pomoc społeczna; } \\
\text { R - działalność związana z kultura, rozrywką } \\
\text { i rekreacja; S - pozostała działalność usługowa }\end{array}$ \\
\hline
\end{tabular}

Uwagi: Szerzej na temat dźwigni finansowej można znaleźć w Berent (2013, s. 26-35).

Źródło: Opracowanie własne.

AUNC, EKONOMIA XLVII nr 1 (2016) 7-26 


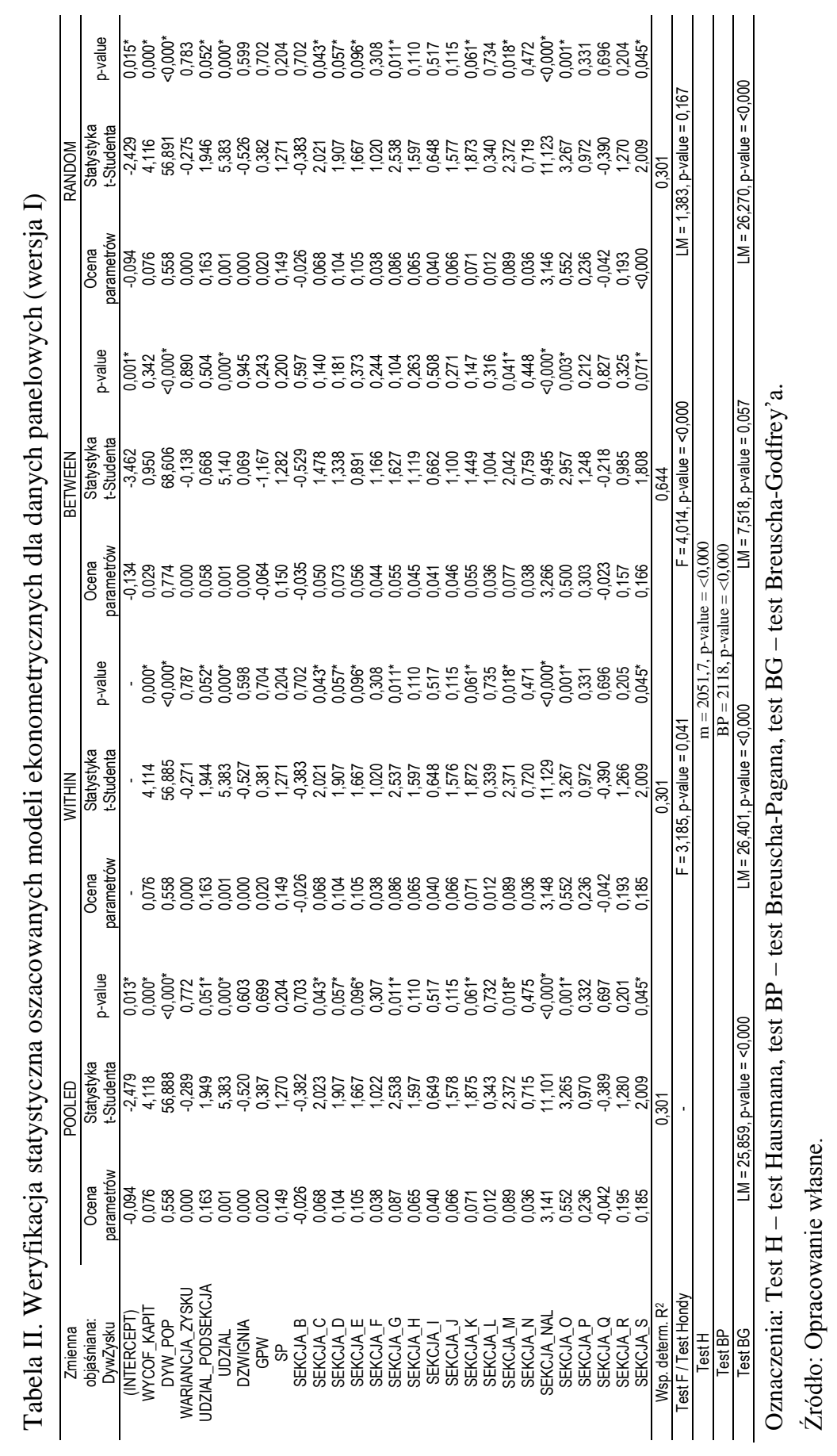




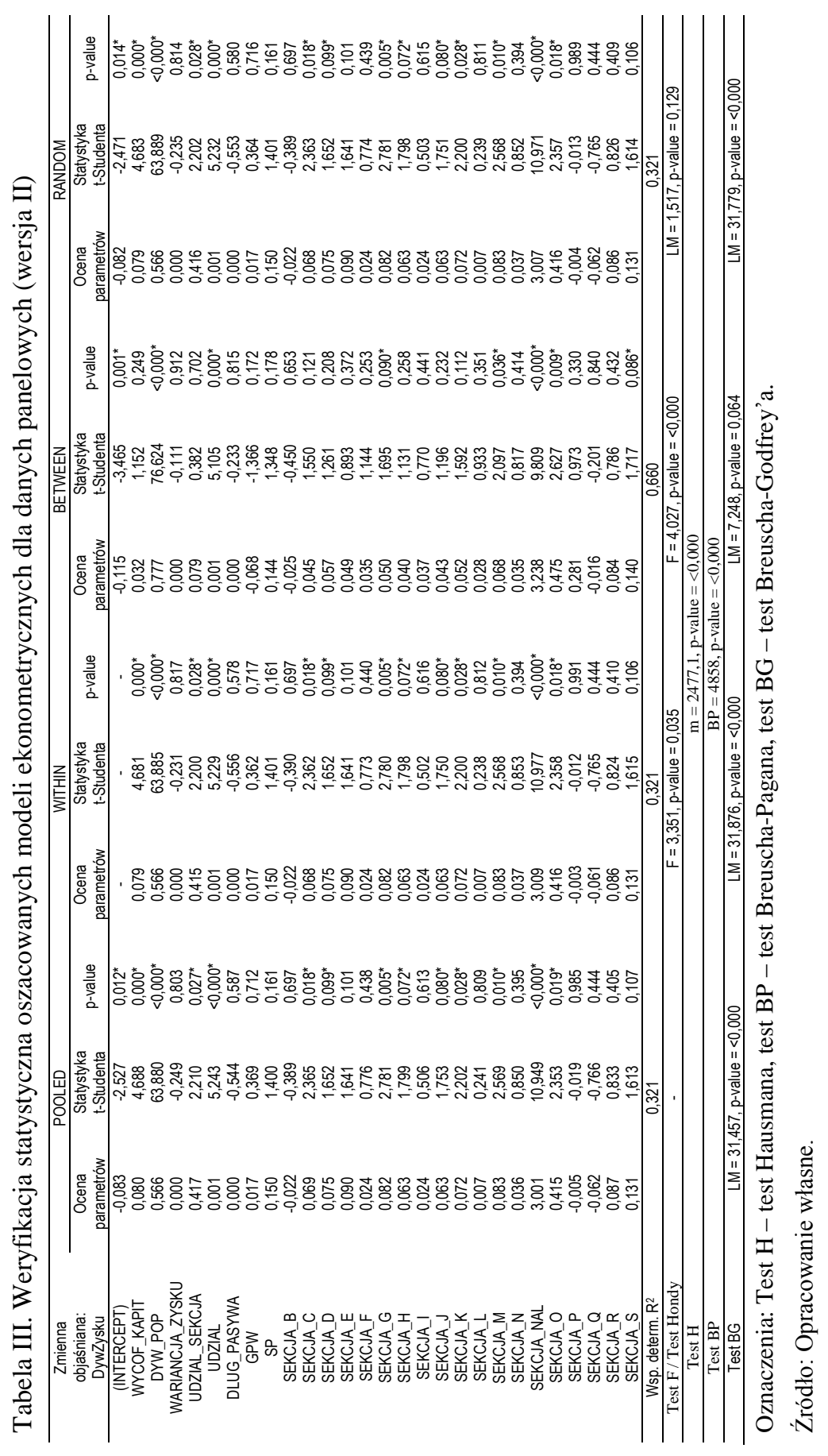

